\title{
Human adaptation strategies to abrupt climate change in Puerto Rico ca. 3.5 ka
}

\author{
Isabel Rivera-Collazo,' Amos Winter, ${ }^{2}$ Denis Scholz, ${ }^{3}$ Augusto \\ Mangini, ${ }^{4}$ Thomas Miller, ${ }^{5}$ Yochanan Kushnir ${ }^{6}$ and David Black ${ }^{7}$
}

\begin{abstract}
The connection between climatic change and social response is complex because change articulates a number of inter-related factors. Human decisions are filtered by social buffers - including social memory, risk perception, and cultural priorities - and the rate and scale of climate change is usually much larger than the scale of human decision-making. In this article, we provide information on climate change based on precisely dated speleothems with the response evident in archaeological sites that have radiocarbon date ranges within the same time frame. A stalagmite recovered from within the catchment area for aquifer recharge of the Pre-Arawak site of Angostura in Barceloneta, Puerto Rico, shows that a significant wet period occurred between 3.9 and $3.1 \mathrm{ka}$ (primarily centered at $3.5 \mathrm{ka}$ ). We investigate the effect that this increase in precipitation had on the earliest occupations on the island in the context of palaeoenvironmental, geoarchaeological, and archaeological records from Angostura, Maruca, and Paso del Indio. Our analysis suggests the presence of two different adaptation strategies: settlement relocation and microlandscape modification. Our study concludes that the social response to change cannot be seen as monolithic given that human behavior, even within the same period, addresses the needs of individual groups with different priorities. This multiplicity of responses can indeed enhance resilience as social support can continue through alliances and exchanges, strengthening social bonds that can help buffer catastrophes. The results can help shed light on the range of adaptation strategies to change encompassed within the manifestations of social resilience or vulnerability.
\end{abstract}

\section{Keywords}

adaptation strategies, archaic period, Caribbean archaeology, climate change, Puerto Rico, speleothem

Received 28 April 2014; revised manuscript accepted 2 I November 2014

\section{Introduction}

Human responses to climate change can be expected to reflect overall social resilience/vulnerability and risk perception. The articulation of climatic changes and social response is complex given that climate change triggers response in other environmental variables, and because human decisions are filtered by social buffers, including social memory, risk perception, and cultural priorities (Adger et al., 2013; Rosen and Rivera-Collazo, 2012). Research can be also complicated in that the rate and scale of climate change are usually much larger than the scale of human decision-making. This article discusses how people during the Archaic or Pre-Arawak period, the earliest human occupiers on the island of Puerto Rico, coped with an increase in precipitation around 3500 years ago $(\mathrm{ka})$. Our results shed light on the range of human adaptive strategies to climate change.

\section{General climate and environmental context for the Greater Antilles}

The time period under study (i.e. the mid- to beginning of the late Holocene, 6-3 ka) coincided with the end of a period of intensified solar forcing (insolation) by the precession cycle, a process that peaked at $\sim 9 \mathrm{ka}$. Northern Hemisphere $(\mathrm{NH})$ climate characteristics of this high-insolation interval (termed the Holocene Climatic Optimum) were different than today owing to the overall higher sea-surface temperatures (SSTs) in summer and the larger land-sea contrast during winter. This influenced the Intertropical Convergence Zone (ITCZ) to migrate further north, reaching the Greater Antilles during summer (Braconnot et al., 2000; Gyllencreutz et al., 2010; Wanner et al., 2008). The convection band of the ITCZ also widened between 6 and $3 \mathrm{ka}$, affecting a larger area than at present and depositing a further $2-4 \mathrm{~mm}$ of rain per day

'Department of Sociology and Anthropology and Center for Applied Tropical Ecology and Conservation, University of Puerto Rico at Rio Piedras, Puerto Rico

2Department of Marine Sciences, University of Puerto Rico at Mayaguez, Puerto Rico

${ }^{3}$ Institute for Geosciences, University of Mainz, Germany ${ }^{4}$ Heidelberger Akademie der Wissenschaften, Germany ${ }^{5}$ Department of Geology, University of Puerto Rico at Mayaguez, Puerto Rico

'Lamont-Doherty Earth Observatory of Columbia University, USA ${ }^{7}$ Stony Brook University, USA

\section{Corresponding author:}

Isabel Rivera-Collazo, Department of Sociology and Anthropology and Center for Applied Tropical Ecology and Conservation, University of Puerto Rico at Rio Piedras, PO Box 23345, San Juan, 0093I-3345 Puerto Rico.

Email: isabel.rivera2@upr.edu 
compared with modern conditions (Braconnot et al., 2007). The northern sections of South America and the Greater Antilles therefore saw wetter wet seasons and drier dry seasons (Burney et al., 1994; Curtis et al., 1999; Greer and Swart, 2006; HigueraGundy et al., 1999; Hodell et al., 1991; Kennedy et al., 2006; Milne et al., 2005; Nyberg et al., 2001; Peros et al., 2007). These changes also led to the intensification of the African summer monsoon and a weakening of the El Niño Southern Oscillation (ENSO) variability (Clement et al., 2000; Moy et al., 2002), which in turn influenced the regular path and intensity of Atlantic tropical storms (Bertran et al., 2004; Donnelly and Woodruff, 2007; Haug et al., 2001; Malaizé et al., 2011; Woodruff et al., 2008a, 2008b).

Geologically, the north coast of Puerto Rico is characterized, from south to north, by a ridge of volcanic mountains (Central Cordillera) reaching a wide karstic region, which continues north into the Atlantic Ocean. These limestone deposits, accumulated between the Oligocene and the Pliocene, constitute the largest water reservoir of the island, consisting of confining and aquifer units that store precipitation and feed a vast underground drainage system (Renken et al., 2002). Further south in the karst, it is characterized by numerous caves and mogotes and increasing thickness of the unsaturated area. Precipitation influences groundwater recharge, which occurs by rapid infiltration with little evaporation (Jones and Banner, 2003; Taylor et al., 2013). Given the characteristics of the climate of the study area, aquifer recharge in the southern karst occurs mostly during the wet season of June-November.

\section{Case study: Precipitation reconstruction from speleothems}

Speleothems are increasingly used as terrestrial archives of past climate and environmental change because they provide long, continuous, high-resolution time series that can be precisely dated by uranium-series disequilibrium methods and are generally unaffected by post-depositional diagenetic alteration (Fairchild et al., 2006). The growth rates of speleothems are related to changes in climatic parameters (Lachniet et al., 2012). In the tropics, seasonal precipitation amounts (above individual cave-dependent thresholds) are most likely the primary variable affecting annual speleothem growth (Burns, 2002), but soil activity above the cave and temperature may also be important (Kaufmann, 2003; White, 2004). Hiatuses in speleothems are usually related to periods of climate change, primarily droughts, but may, on occasion, also be because of changes in cave morphology (earthquakes) or hydrologic patterns (Cruz et al., 2005, Van Beynen et al., 2007).

Our data derive from a stalagmite (PA 2b) collected in 2005, $100 \mathrm{~m}$ inside the cavern of Palco located in the Lares Limestone rock formation in the Ciales municipality of Puerto Rico (Figure $\left.1, \sim \mathrm{N} 18.35^{\circ} / \mathrm{W} 66.5^{\circ}\right)$. The in-cave elevation is 250 m.a.s.l., with a mean annual cave temperature of $23^{\circ} \mathrm{C}$. No formal monitoring has been undertaken, although temperatures, atmospheric $\mathrm{CO}_{2}$, and ${ }^{18} \mathrm{O}$ isotopes have been collected on several occasions. Entry to the cave is via a restricted series of rooms (requiring crawling at one point) that insulate the large interior chambers from outside atmospheric influences. This together with its active dripping at the time of collection and candle-shape were factors in choosing PA $2 b$ for analysis. The stalagmite is $29.25 \mathrm{~cm}$ long, with a rounded top and does not show a 'cup' that could imply drip erosion. The thickness of the rock overburden at the cave is $50-70 \mathrm{~m}$, tending to increase the lag between rainfall and drip response in the cave (Miller, 2004, 2009).

\section{Methods}

For ${ }^{230} \mathrm{Th} / \mathrm{U}$-dating, 12 powder samples, each weighing approximately $200 \mathrm{mg}$, were extracted with a hand-held dental drill along growth layers from a polished slab section of PA $2 b$. Two ages (PA 2b-3 and PA 2b-8) were determined using a thermal ionization mass spectrometer (TIMS) Finnigan MAT 262 RPQ housed at the Heidelberg Academy of Sciences. The other 10 samples were analyzed with a multi-collector inductively coupled plasma mass spectrometer (MC-ICPMS) located at the Max Planck Institute for Chemistry (MPIC), Mainz. The samples were prepared similarly as described in Frank et al. (2000) for TIMS and Hoffmann et al. (2007) for MC-ICPMS. The calibration of the mixed ${ }^{229} \mathrm{Th}-{ }^{233} \mathrm{U}-$ ${ }^{236} \mathrm{U}$ spike used at MPIC is described in Zak et al. (2012) and Scholz et al. (2014). Analytical MC-ICPMS techniques involved a standard-sample bracketing procedure to derive correction factors for mass fractionation and Faraday cup to ion counter gain, as described in Hoffmann et al. (2007), Jochum et al. (2011), and Scholz et al. (2014). All activity ratios reported for both laboratories were calculated using the decay constants from Cheng et al. (2000).

For stable isotope analysis, PA $2 \mathrm{~b}$ was continuously milled at $0.3-\mathrm{mm}$ intervals using a SHERLINE 5410 milling machine. The samples were analyzed using a continuous flow IsoPrime Multiflow System at the Geology Department at the University of Puerto Rico. Samples were transferred into $10-\mathrm{mL}$ borosilicate vials and sealed with Butyl rubber septa (Labco, High Wycombe, UK). Subsequently, 61 samples and 18 internal standards were heated in the Gasbench tray to $72 \pm 0.1^{\circ} \mathrm{C}$, and analyzed on a Gasbench II carbonate periphery. For analysis, the carbonate samples were dissolved in 3-5 drops of orthophosphoric acid under helium (grade 5) atmosphere. Four sample gas aliquots were carried through a Nafion trap to remove residual water before entering the Valco multi-injection loop. The gas mixture $\left(\mathrm{CO}_{2}\right.$ and $\left.\mathrm{He}\right)$ was introduced into a gas chromatographic column (Poraplot Q) and the $\mathrm{CO}_{2}$ separated from other gases. After passing a second water trap, the analyte was introduced into the mass spectrometer. NBS 19 was used as in-house reference material, with isotope ratios $\left({ }^{18} \mathrm{O} /{ }^{16} \mathrm{O}\right.$ and $\left.{ }^{13} \mathrm{C} /{ }^{12} \mathrm{C}\right)$ reported in standard delta notation relative to the Vienna Pee Dee Belemnite standard (\%o VPDB).The external analytical precision for both $\delta^{13} \mathrm{C}$ and $\delta^{18} \mathrm{O}$ is better than $0.06 \%$.

\section{Results and discussion}

The results of ${ }^{230} \mathrm{Th} / \mathrm{U}$-dating for PA $2 \mathrm{~b}$ are shown in Table 1 and Figure 2. The ${ }^{238} \mathrm{U}$ content ranges from 0.197 to ca. $0.578 \mu \mathrm{g} / \mathrm{g}$, and the ages range from $0.2535 \pm 0.0095$ to $6.987 \pm 0.067 \mathrm{ka}$. The stalagmite exhibits three growth phases (Figure 2): 7-5.5 ka (bottom), 3.9-3.1 ka (middle), and the last 200 years (top). The age determined at the top of PA $2 \mathrm{~b}-1$ (i.e. at $10.4 \mathrm{~mm}$ distance from top (dft)) is significantly older than the age at $21.8 \mathrm{~mm} \mathrm{dft}$ and consequently represents an age inversion (Figure 2). Since this sample has the lowest $\left({ }^{230} \mathrm{Th} /{ }^{232} \mathrm{Th}\right.$ ) ratio of all samples (Table 1), the age inversion is probably because of contamination with detrital ${ }^{230} \mathrm{Th}$.

Application of the 'standard' correction for detrital contamination, assuming a bulk Earth ${ }^{232} \mathrm{Th} / 238 \mathrm{U}$ weight ratio of 3.8 and ${ }^{230} \mathrm{Th},{ }^{234} \mathrm{U}$, and ${ }^{238} \mathrm{U}$ in secular equilibrium, results in insignificant age changes for all samples. However, several speleothem studies, in particular from the Caribbean, have shown that a much lower ${ }^{232} \mathrm{Th} /{ }^{238} \mathrm{U}$ weight ratio of the detrital component may be required for appropriate correction for detrital contamination (Beck et al., 2001; Fensterer et al., 2010, 2012; Hellstrom, 2006; Hoffmann et al., 2010; Richards and Dorale, 2003). Using the stratigraphic constraint that the age of the speleothem must increase with increasing dft, the ${ }^{232} \mathrm{Th} /{ }^{238} \mathrm{U}$ weight ratio of the detritus can be estimated (Hellstrom, 2006). Sample PA 2b-1 is ideal for this purpose because it (1) is very young and (2) has a very low $\left({ }^{230} \mathrm{Th} / 232 \mathrm{Th}\right)$ ratio (Table 1) and is thus largely affected by the correction. Its age must be younger than the age of the sample below (PA 2b-2), but older than AD 2005 (i.e. the year of the collection of the stalagmite). This tightly constrains 


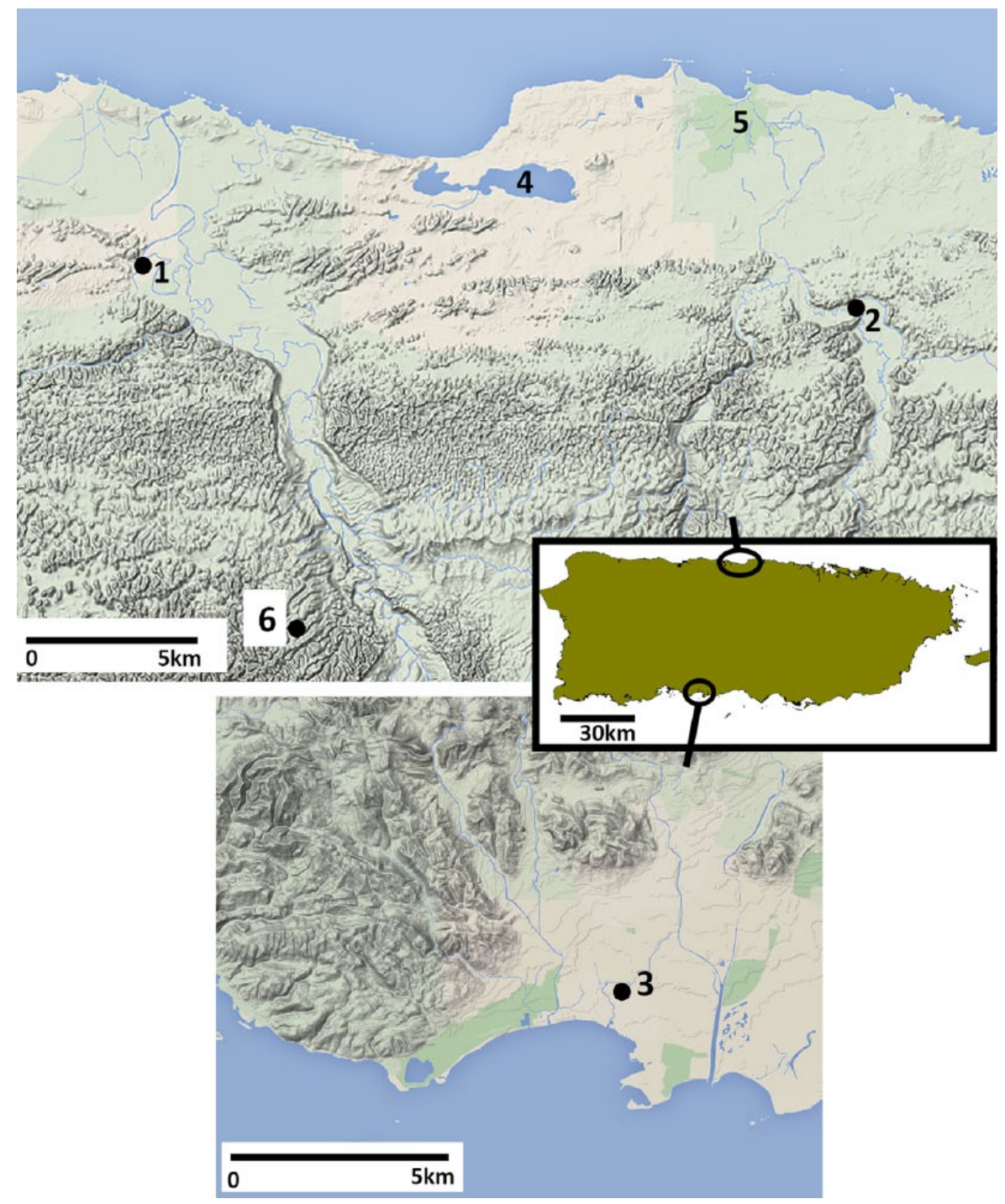

Figure I. Location of sites mentioned in the text. The approximate coordinates for each are (I) Angostura NI8.44 $/$ W66.54 ${ }^{\circ}$, (2) Paso del

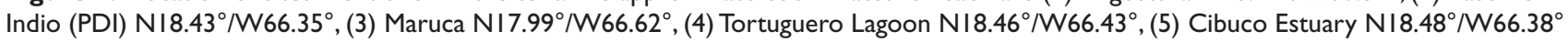
and (6) Palco Cave NI8.35\% $66.5^{\circ}$. Precise coordinates are not provided for the archaeological sites or for Palco Cave to protect their location.

the age and consequently the ${ }^{232} \mathrm{Th} /{ }^{238} \mathrm{U}$ weight ratio of the detritus. The resulting ${ }^{232} \mathrm{Th} / 238 \mathrm{U}$ weight ratio of the detritus is $0.35 \pm 50 \%$, which is of the same magnitude as reported in other speleothem studies from the Caribbean (Beck et al., 2001; Fensterer et al., 2010, 2012; Hoffmann et al., 2010). Application of this value to the whole data set resolves all age inversions and results in generally younger ages (Figure 2). However, despite of the lower ${ }^{232} \mathrm{Th} / 238 \mathrm{U}$ value compared with the 'standard' approach, the correction is only significant for two samples (PA $2 b-1$ and $2 b-4$, Figure 2, Table 1). Because of the correction, the uncertainty of all ages increases, which is particularly important for the samples with a low $\left({ }^{230} \mathrm{Th} / 232 \mathrm{Th}\right)$ ratio (Table 1, Figure 2).

The chronology of PA $2 b$ is constrained by $12{ }^{230} \mathrm{Th} / \mathrm{U}$-ages. In addition, we assume an age of AD 2005 for the top of PA $2 b$ because it was actively dripping at the time of collection. The age model was constructed using StalAge (Scholz and Hoffmann, 2011), a software specifically developed for construction of speleothem age models. Because of the relatively large effect of detrital contamination on samples PA 2b-3 and 2b-4 (Figure 2), the age uncertainty of the younger part of the middle section, as estimated by StalAge, is relatively large. Nevertheless, the growth rate of the middle section is between 100 and $200 \mu \mathrm{m} / \mathrm{a}$ and thus relatively large.
It is possible that the middle section of PA $2 \mathrm{~b}$ grew during a shorter interval of time than the 800 years estimated by the (relatively uncertain) age model. In this case, the growth rate would be similar as for the bottom section that grew during 7 and $6 \mathrm{ka}$ (Figure 2). Fast growth during only relatively short intervals in Caribbean speleothems has been observed for several other stalagmites during the Holocene (Winter et al., 2014). The period of relatively fast growth observed here between 4 and $3 \mathrm{ka}$ for PA $2 \mathrm{~b}$ has yet to be found in other speleothems. Although we cannot exclude local features, such as a change in aquifer characteristics causing the increase in growth, the most likely explanation given for fast tropical speleothem growth is high precipitation (Kaufmann, 2003; Proctor et al., 2000). Supporting the connection between precipitation and speleothem growth is the fact that stalagmite PA $2 \mathrm{~b}$ has been growing for the last 200 years, a time when precipitation increased after the pervasive droughts of the 'Little Ice Age' (Kennett et al., 2012).

The $\delta^{18} \mathrm{O}$ values of speleothem calcite precipitated at constant temperature deep within the cave are sensitive recorders of varying rainfall amounts that accumulated in the overlying aquifer in Puerto Rico. This is because there is a large negative isotope fractionation in the tropics that accompanies the distillation of rainwater from clouds (Dansgaard, 1964; Winter et al., 2011). $\delta^{18} \mathrm{O}$ values during 3.9-3.1 ka growth phase and for the recent period 
Table I. ${ }^{230} \mathrm{Th}$ dating results. The error is $2 \sigma$ error. Corrected ages were calculated assuming a bulk earth ${ }^{232} \mathrm{Th} / 238 \mathrm{U}$ value of $3.8 \pm 50 \%$ and secular equilibrium between ${ }^{230} \mathrm{Th},{ }^{234} \mathrm{U}$, and ${ }^{238} \mathrm{U}$. Corrected age represents calendar years, before year of analysis $(2013)$.

\begin{tabular}{|c|c|c|c|c|c|c|c|c|c|c|c|c|}
\hline Sample & $\begin{array}{l}238 U \\
(\mu g / g)\end{array}$ & \pm & $\left({ }^{234} U / 238 U\right)$ & \pm & $\left({ }^{230} \mathrm{Th} / 238 \mathrm{U}\right)$ & \pm & $\left({ }^{230} \mathrm{Th} / 232 \mathrm{Th}\right)$ & \pm & $\begin{array}{l}\text { Age uncorrected } \\
\text { (ka) }\end{array}$ & \pm & $\begin{array}{l}\text { Age corrected } \\
(\mathrm{ka})^{\mathrm{a}}\end{array}$ & \pm \\
\hline PA 2b-I & 0.197 & 0.001 & 2.6159 & 0.0053 & 0.01656 & 0.00033 & 14.3 & 0.3 & 0.6930 & 0.0140 & 0.2697 & 0.2056 \\
\hline PA 2b-2 & 0.262 & 0.002 & 2.630 & 0.015 & 0.00610 & 0.00022 & 47.4 & 2.1 & 0.2535 & 0.0095 & 0.2069 & 0.0248 \\
\hline PA 2b-3b & 0.2233 & 0.0004 & 2.599 & 0.013 & 0.0794 & 0.0077 & 122.4 & 11.9 & 3.38 & 0.34 & 3.142 & 0.352 \\
\hline PA 2b-4 & 0.216 & 0.001 & $2.604 I$ & 0.0042 & 0.08627 & 0.00083 & 62.34 & 0.78 & 3.667 & 0.037 & 3.162 & 0.240 \\
\hline PA $2 b-6$ & 0.225 & 0.001 & 2.5907 & 0.0051 & 0.08897 & 0.00090 & 477.4 & 7.4 & 3.803 & 0.040 & 3.735 & 0.050 \\
\hline PA 2b-7 & 0.254 & 0.002 & 2.582 & 0.012 & 0.0915 & 0.0013 & 1388.1 & 92.1 & 3.928 & 0.059 & 3.903 & 0.061 \\
\hline PA 2b-8b & 0.3025 & 0.0006 & 2.578 & 0.010 & 0.1335 & 0.0083 & I852.| & 123.8 & 5.78 & 0.36 & 5.75 & 0.37 \\
\hline PA 2b-9 & 0.295 & 0.002 & 2.5548 & 0.0048 & 0.12626 & 0.00098 & 1994.4 & 29.5 & 5.508 & 0.045 & 5.484 & 0.045 \\
\hline PA $2 b-10$ & 0.263 & 0.002 & 2.5509 & 0.0059 & 0.1479 & 0.0014 & 6536.4 & 808.0 & 6.485 & 0.063 & 6.477 & 0.063 \\
\hline PA 2b-II & 0.369 & 0.002 & 2.5530 & 0.0067 & 0.1500 & 0.0012 & 1724.7 & 38.4 & 6.576 & 0.058 & 6.544 & 0.062 \\
\hline PA $2 b-12$ & 0.389 & 0.002 & 2.5493 & 0.0044 & 0.1511 & 0.0013 & 6846.5 & 255.9 & 6.634 & 0.061 & 6.626 & 0.061 \\
\hline PA $2 b-13$ & 0.578 & 0.004 & 2.5438 & 0.0039 & 0.1586 & 0.0015 & 6039.6 & 159.6 & 6.987 & 0.067 & 6.977 & 0.068 \\
\hline
\end{tabular}

a Corrected ages were calculated using a ${ }^{232} \mathrm{Th} /{ }^{238} \mathrm{U}$ weight ratio of the detritus of $0.35 \pm 50 \%$ and assuming $\left({ }^{230} \mathrm{Th},{ }^{234} \mathrm{U}\right.$, and ${ }^{238} \mathrm{U}$ in secular equilibrium (see main text for details).

bSamples dated by TIMS.

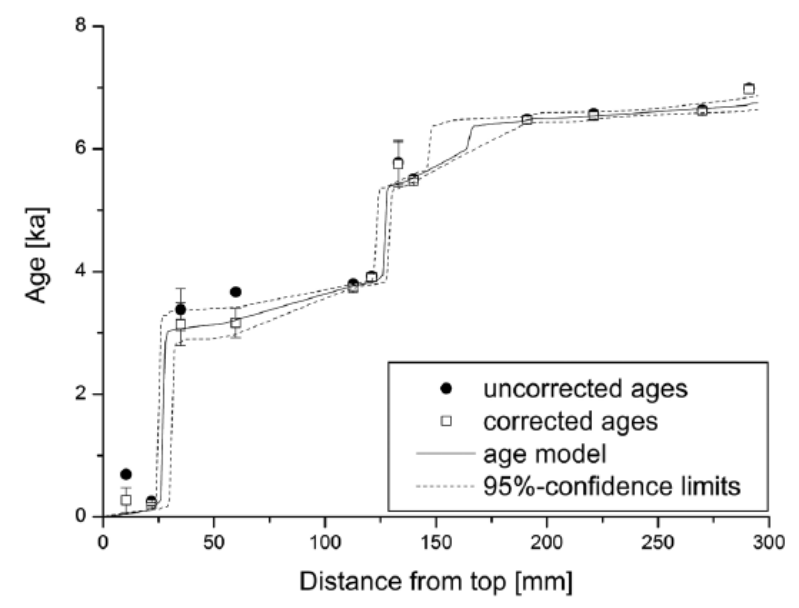

Figure 2. Age model of Palco $2 b$ based on StalAge (Scholz and Hoffmann, 20I I), showing that the stalagmite grew rapidly $(8 \mathrm{~cm})$ around $3.5 \mathrm{ka}$.

(last 200 years) are shown in Figure 3. The variability (i.e. $-2.5 \%$ to $-3.5 \%$ in both cases) is equivalent to a $50-70 \mathrm{~mm}$ change in average annual precipitation (Winter et al., 2011). The mean value of the $\delta^{18} \mathrm{O}$ values for both time periods $(-3.1 \%$ ) are also nearly identical. This suggests that similar precipitation conditions occurred during both time intervals and that $50-70 \mathrm{~mm} / \mathrm{yr}$ average rainfall may be the threshold for stalagmite growth at Palco cave.

The 3.9-3.1 ka growth phase in PA $2 \mathrm{~b}$ fits between two $\mathrm{NH}$ cold events at $\sim 4$ and $\sim 3.2 \mathrm{ka}$ (Mayewski et al., 2004; Zhang et al., 2000 ), probably representing a break in the cold conditions and, thus, a return of the ITCZ to a position further north. The Cariaco Basin record (Haug et al., 2001) coincides with our observations as higher concentrations of Ti and Fe between 3.7 and $3.5 \mathrm{ka}$ indicate a northern location of the ITCZ, meaning higher rainfall in the Caribbean. Just before $3 \mathrm{ka}$, Ti in Cariaco dropped as the ITCZ shifted southward, coinciding with the end of speleothem growth in PA $2 b$.

\section{Social context of Puerto Rico at the end of the mid-Holocene}

It has been previously thought that the earliest occupations of Puerto Rico, collectively referred to as Pre-Arawak or Archaic
Period, comprised small bands of mobile hunter-gatherers. However, recent research has led to the re-evaluation of this characterization (Rivera-Collazo, 2011b, 2011c; Rodríguez Ramos, 2008, 2010). Sites such as Maruca, Paso del Indio (PDI), and Angostura indicate the presence of permanent settlements on open-air areas near rivers or coasts, providing easy access to the sea (RiveraCollazo, 2011b). The material culture assemblage of the period suggests long-distance webs of interaction with other islands and the Caribbean coasts of South and Central America, particularly the Isthmo/Colombian area (Pagán Jiménez, 2007, 2011; Rodríguez Ramos, 2010).

Exchange and long-distance webs of interaction during the Archaic Period were significant drivers of social dynamics and settlement patterns, including sedentism or permanent settlement within hunter-gatherer socioeconomic contexts (Rivera-Collazo, 2011b; Rodríguez Ramos, 2010). Radiocarbon dates from archaeological studies (Rodríguez Ramos, 2010: 44) indicate that Puerto Rico was initially occupied ca. $4.8 \mathrm{ka}$ (4713 cal. BP (intercept, $2 \sigma 95.4 \%$ ) from Maruca, Puerto Rico). The archaeological record during the Archaic Period suggests cultural continuity without significant social change until after the beginning of the Ceramic Age/Saladoid Period (ca. 2.0-1.9 ka). No change in social parameters of the Archaic Period is evidenced in the archaeological record that could explain adaptive responses as discussed in this paper.

\section{Case study:Archaeology}

In order to evaluate what effect, if any, the $3.5 \mathrm{ka}$ wet period had over the social groups living in Puerto Rico, we selected Angostura, Maruca, and Paso del Indio (PDI; Figure 1). These three sites are archaeological deposits where permanent settlement occurred during the Archaic Period, with radiocarbon dates overlapping the wet period identified in the PA $2 \mathrm{~b}$ speleothem. In this paper, we look at these sites in a higher detail than ever before - acknowledging the gaps in archaeological research - in order to examine what happened at each site during the $3.5 \mathrm{ka}$ wet period.

The data on Maruca and PDI discussed here are based on the stratigraphic, chronostratigraphic, and archaeological records included in published and unpublished reports (Clark et al., 2003; García Goyco, 1998; García Goyco and Maurás Casillas, 1993; Pantel, 1994; Rodríguez, 1997, 2004; Rodríguez Ramos, 2010; Walker, 2005) and reexamined within the context of the new palaeoclimate data discussed above. 


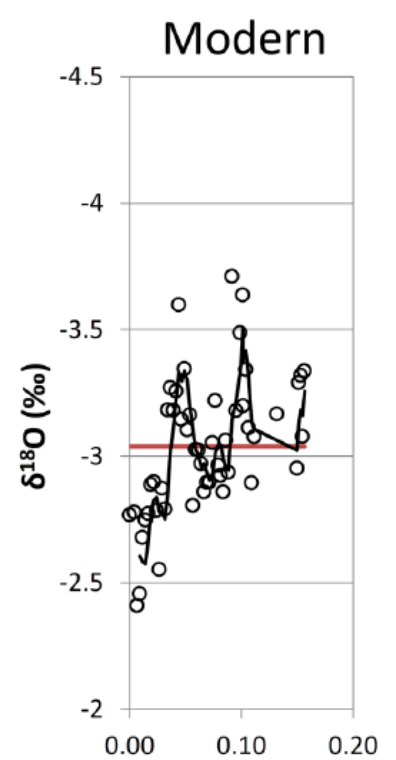

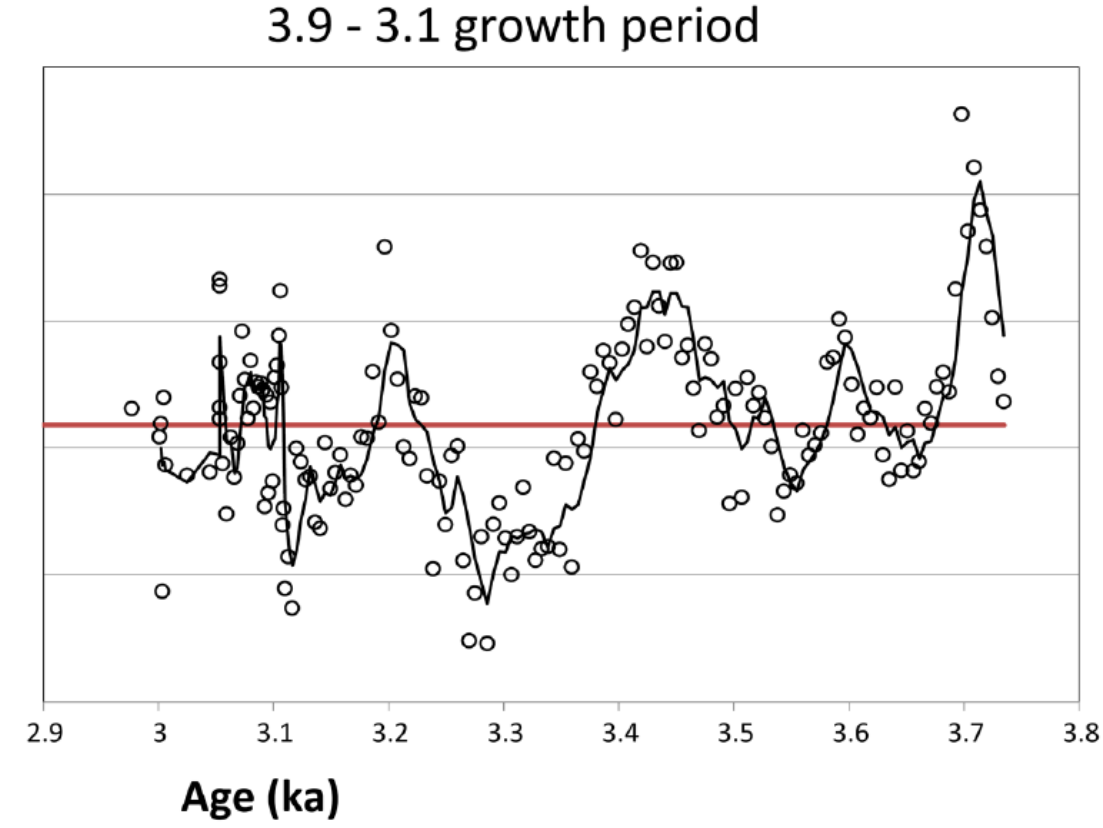

\section{- Palco $2 b$ d180}

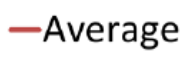

\section{-4 yr mov. average}

Figure 3. Comparison of modern $\delta I 80$ values analyzed from Palco $2 b$ (left) and $\delta I 80$ values analyzed from the same speleothem during the 3.5 ka growth period (right). $\delta 180$ values in the stalagmite are an indication of the amount of precipitation (amount effect, Dansgaard, 1964). The straight line indicates average values of the isotopes, while the line in between the values marks the 4-year moving average. Note the similarity of both records indicating similar conditions.

For Angostura, however, we are evaluating primary data recovered from excavations conducted by the first author. Angostura is located within the Grande de Manatí hydrological basin within the hydrological system that encompasses the Palco cave - on the west bank of the Grande de Manatí River, at the contact between the karstic hill and the coastal plain. The archaeological deposits are concentrated on four mounds (A, B, C, and D), which overlie limestone outcrops, and on the lower area in between the mounds, where black anthrosols were identified. The earliest settlers cleared the tropical forest covering the area, possibly using fire, and settled on the forest soil over the limestone bedrock, which is identified as yellow clay with shallow A-horizon.

\section{Geoarchaeological methods for Angostura}

Accelerator mass spectrometry (AMS) radiocarbon dates were obtained from mounds $\mathrm{B}$ and $\mathrm{C}$, and from the anthrosol area adjacent to mound B (Beta Analytic Laboratories). Other radiocarbon dates (AMS and conventional) were reported in previous excavations (Ayes, 1988; Vega, 2000). All were calibrated with OxCal4.1 using Marine09 or IntCal09 as appropriate (Table 2). The occupational history of the rest of the site was reconstructed through stratigraphic analysis, which included a detailed geoarchaeological evaluation of the deposits: grain size, organic and carbonate content $\left(\mathrm{OM}\right.$ and $\left.\mathrm{CaCO}_{3}\right)$, phosphates, magnetic susceptibility (Table 3), and microartifact analysis (Tables 4 and 5). Grain size analysis combined dry sieving method for the coarse fraction and hydrometer method for the fine fraction (Goldberg and Macphail, 2006). The coarse fraction ( $>1 \mathrm{~mm}$ ) was removed from the sample through wet sieving after disaggregating the mineralogical components using a sodium hexametaphosphate solution (Calgon $5 \%$ ). The finer fraction (including fine sand) was collected in a $1000 \mathrm{~mL}$ cylinder where the density of the sediment suspended in the water column was measured in $\mathrm{g} / \mathrm{L}$ using a hydrometer. Readings were taken at set intervals between $30 \mathrm{~s}$ and $24 \mathrm{~h}$. Corrected readings were calculated after deducting the reading obtained from a control cylinder containing distilled water and Calgon.
The coarse fraction was weighed and sieved using nested sieves separating them into different $\Phi$ sizes.

After dry sieving, all the coarser fractions were retained for multifraction microartifact analysis $(4,2,1,0.5,0.25,0.125$, and $0.063 \mathrm{~mm}$ fractions). Samples were inspected under an incidentlight microscope and percentages of artifact content per fraction were estimated visually using the chart from Bullock et al. (1985: 24-25). In addition, the contents of the field-collected $3 \mathrm{~mm}$ mesh sieves were sorted and analyzed for size-specific microartifact analysis. A statistical random sample of $1.15 \mathrm{~L}$ was selected for study.

Loss on ignition (LOI) was used for determining the organic (OM LOI) and carbonate $\left(\mathrm{CaCO}_{3} \mathrm{LOI}\right)$ contents of the samples. OM LOI samples, consisting of approximately $10 \mathrm{~g}$ of sediment, were fired in a furnace at $550^{\circ} \mathrm{C}$ for $1.5 \mathrm{~h}$ and allowed to cool in a desiccator to room temperature. For calculating the $\mathrm{CaCO}_{3}$, the samples were returned to the furnace and fired at $1000^{\circ} \mathrm{C}$ for $1 \mathrm{~h}$ after reaching peak temperature. The samples were left to cool in the furnace overnight.

Phosphorous content was calculated using the Gundlach Method, where presence of phosphorous is revealed by a blue color and is expressed in terms of a subjective relative visual scale from 0 to 3 , where 0 is no blue tint and 3 is strong blue radiating bands. For this test, $50 \mathrm{mg}$ of sample was placed on the center of an ash free filter paper. Two drops of acid ammonium molybdate solution were added to the sample, followed, $30 \mathrm{~s}$ later, by two drops of ascorbic acid. Given that blue color even in weak samples continues to develop with time, readings were taken at a standardized time of $2 \mathrm{~min}$.

Magnetic susceptibility $(\chi)$ was measured using a Bartington MS2 meter with a MS2B sensor. For each sample, $10 \mathrm{~g}$ of sediment was placed in diamagnetic containers. Readings of all samples were first made in low frequency followed by high frequency $(0.46$ and $4.6 \mathrm{kHz})$. In order to determine maximum potential, the samples were submitted to an oxidation and reduction cycle in the furnace: $10 \mathrm{~g}$ of dry sample was mixed with $1 \mathrm{~g}$ of plain flour and placed in $25 \mathrm{~mL}$ porcelain crucibles. The 
Table 2. Radiocarbon dates from Angostura, calibrated with OxCal4.I using Marine09 for shell samples and IntCal09 for all others. AMS samples are marked $*$ and conventional, + . Samples collected by the author (Rivera-Collazo) are marked ${ }^{\wedge}$.All the other radiocarbon dates were published by Ayes (1988) or Vega (2000).

\begin{tabular}{|c|c|c|c|c|c|c|}
\hline Lab no. & Material & Locus - context & $\begin{array}{l}\text { Depth ( } \mathrm{cm} \\
\text { below surface) }\end{array}$ & ${ }^{14} \mathrm{C}$ age & $\begin{array}{l}\text { Calibrated age (cal. BP; } 2 \sigma \text {, } \\
95.4 \% \text { probability) }\end{array}$ & $\begin{array}{l}\text { Median of calibrated age } \\
\text { (cal. BP; } 2 \sigma, 95.4 \% \text { ) }\end{array}$ \\
\hline GX-28808 & Charcoal* & Mound B - midden & ca. $7-39$ & $3670 \pm 40$ & $4|44-4| 2 \mid ; 4094-3888$ & 4003 \\
\hline GX-28806 & Charcoal* & Mound B - midden & ca. 7-39 & $3570 \pm 40$ & $3979-3816 ; 3797-3723$ & 3870 \\
\hline GX-28805 & Charcoal* & $\begin{array}{l}\text { Mound B - habitation } \\
\text { surface }\end{array}$ & ca. 39-63 & $3700 \pm 30$ & $\begin{array}{l}4147-4115 ; 4100-3967 \\
3944-3930\end{array}$ & 4037 \\
\hline GX-28807 & Charcoal* & $\begin{array}{l}\text { Mound B - forest soil/ } \\
\text { first habitation surface }\end{array}$ & $>99$ & $3920 \pm 40$ & $45 \mathrm{II}-4484 ; 4442-4239$ & 4354 \\
\hline Beta-29778 & Charcoal+ & Mound B - unknown & Unknown & $5960 \pm 250$ & $\begin{array}{l}74|4-7392 ; 737|-7356 \\
7330-6300\end{array}$ & 6820 \\
\hline GX-28809 & Charcoal* & Mound B - midden & ca. $39-63$ & $3470 \pm 40$ & $3840-3638$ & 3749 \\
\hline GX-28810 & Shell+ & Mound B - shell layer & ca. 63-99 & $3980 \pm 80$ & $4226-3761$ & 3986 \\
\hline GX-288I3 & Shell+ & Mound B - shell layer & ca. 63-99 & $4010 \pm 70$ & $4229-3829$ & 4024 \\
\hline GX-288I4 & Charcoalt+ & Mound B - shell layer & ca. $63-99$ & $3740 \pm 100$ & $4413-3860$ & 4108 \\
\hline GX-288II & Shell+ & Mound B - shell layer & ca. 63-99 & $3830 \pm 90$ & $3932-3419$ & 3672 \\
\hline GX-288I2 & Shell+ & $\begin{array}{l}\text { Mound B - forest soil/ } \\
\text { first habitation surface }\end{array}$ & $>99$ & $4 \mid 20 \pm 80$ & $4048-3556$ & 3784 \\
\hline Beta-294435^ & Charred material* & $\begin{array}{l}\text { Unit } 3 \text { - Shell layer/ } \\
\text { Anthrosol }\end{array}$ & $74-80$ & $2120 \pm 30$ & $2295-2270 ; 2155-1998$ & 2093 \\
\hline Beta-294434^ & Charred material* & $\begin{array}{l}\text { Mound C-midden/shell } \\
\text { layer }\end{array}$ & $12-14$ & $3680 \pm 40$ & $4|46-4| 18 ; 4096-3898$ & 4019 \\
\hline Beta-294440^ & Plant material* & Offsite Core 2 & 538 & $3740 \pm 30$ & $4224-4205 ; 4158-3985$ & 4096 \\
\hline Beta-294439^ & Organic sediment* & Offsite Core 4 & 178 & $1890 \pm 30$ & $1895-1732$ & 1839 \\
\hline Beta-294438^ & Plant material* & Offsite Core 3 & 353 & $840 \pm 30$ & $893-878 ; 796-686$ & 747 \\
\hline Beta-294437^ & Wood* & Offsite Core I & 280 & $1430 \pm 30$ & $1376-1293$ & 1327 \\
\hline Beta-294437^^ & Charred material* & Offsite Core 3 & 439 & $660 \pm 30$ & $673-628 ; 603-558$ & 611 \\
\hline
\end{tabular}

AMS: accelerator mass spectrometry.

Table 3. Summary of main results of the geoarchaeological analyses of onsite samples. Grain size is presented as cumulative percentages of

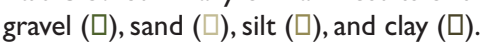

\begin{tabular}{|c|c|c|c|c|c|c|c|}
\hline Locus & Stratum & Grain size & $P$ & $\chi_{\mathrm{LF}}$ & $\chi_{\text {conv }}$ & OM LOI (\%) & $\mathrm{CaCO}_{3} \mathrm{LOI}(\%)$ \\
\hline \multirow[t]{4}{*}{ Mound C } & A & & 3 & 4.4 & 0.10 & 18.12 & 6.40 \\
\hline & B & & 3 & 4.1 & 0.13 & 11.40 & 10.73 \\
\hline & C & & 3 & 1.6 & 0.03 & 12.06 & 2.92 \\
\hline & $D$ & & 2 & 0.5 & 0.01 & 11.02 & 2.11 \\
\hline \multirow[t]{6}{*}{ Unit 3 (Anthropic soil) } & $\mathrm{B}_{\mathrm{up}}$ & & 3 & 3.9 & 0.11 & 15.14 & 2.83 \\
\hline & $B_{\text {low }}$ & & 3 & 4.0 & 0.11 & 18.28 & 0.76 \\
\hline & $C_{\text {west }}$ & & 3 & 4.3 & 0.10 & 13.24 & 1.85 \\
\hline & $C_{\text {east }}$ & & 3 & 4.4 & 0.13 & 13.92 & 3.27 \\
\hline & $C_{\text {mid }}$ & & 3 & 4.8 & 0.12 & - & - \\
\hline & $\mathrm{D}$ & & 3 & 4.3 & 0.15 & 14.04 & 7.86 \\
\hline \multirow[t]{7}{*}{ Mound B } & $\mathrm{F}$ & & 3 & 3.9 & 0.13 & 11.46 & - \\
\hline & $\mathrm{G}_{\mathrm{up}}$ & & 3 & 4.0 & 0.16 & 9.24 & 10.92 \\
\hline & $\mathrm{G}_{\text {low }}$ & & 3 & 4.5 & 0.19 & 8.60 & 10.79 \\
\hline & $\mathrm{H}$ & & 3 & 6.2 & 0.16 & 9.58 & 3.71 \\
\hline & $\mathrm{I}_{\text {up }}$ & & 3 & 5.2 & 0.14 & 11.62 & 4.05 \\
\hline & $\mathrm{I}_{\text {low }}$ & & 3 & 5.0 & 0.14 & 12.14 & 3.88 \\
\hline & J & & 2 & 3.9 & 0.19 & 7.12 & 15.88 \\
\hline
\end{tabular}

LOI: loss on ignition. 
Table 4. Artifact (A) and microartifact (M) content per volume of sampled sediment.

\begin{tabular}{|c|c|c|c|c|c|}
\hline \multirow{2}{*}{$\frac{\text { Locus }}{\text { Mound C }}$} & \multirow{2}{*}{$\begin{array}{l}\text { Stratum } \\
\text { B }\end{array}$} & \multirow{2}{*}{$\begin{array}{l}\text { Sample weight (g) } \\
36.824\end{array}$} & \multirow{2}{*}{$\begin{array}{l}\text { Artifact content (\%) } \\
3.4\end{array}$} & \multicolumn{2}{|c|}{ Microartifact content (\%)M/A ratio } \\
\hline & & & & 26.4 & 7.7 \\
\hline & C & 34.6 & 1.2 & 2.5 & 2.1 \\
\hline & $\mathrm{D}$ & 30.036 & 0.0 & 0.0 & 0.0 \\
\hline \multirow[t]{4}{*}{ Unit 3 (Anthropic soil) } & $\mathrm{Cw}$ & 35.489 & 0.0 & 2.2 & 75.8 \\
\hline & $\mathrm{Cm}$ & 41.018 & 0.6 & 5.6 & 9.1 \\
\hline & $\mathrm{Ce}$ & 43.071 & 1.8 & 2.7 & 1.5 \\
\hline & $\mathrm{D}$ & 34.909 & 1.1 & 20.3 & 17.8 \\
\hline \multirow[t]{4}{*}{ Mound B } & G & 45.036 & 3.4 & 18.7 & 5.4 \\
\hline & $\mathrm{H}$ & 31.103 & 0.6 & 6.5 & 11.6 \\
\hline & I & 30.13 & 0.3 & 6.6 & 20.3 \\
\hline & j & 100.103 & 17.6 & 13.6 & 0.8 \\
\hline
\end{tabular}

Table 5. Percentage of microartifact content per size fraction of studied sample. Identified microartifacts include shell (burnt and unburnt), bone (burnt, unburnt, chewed, and digested), charred organics (including wood, twigs, leaves, and seeds), lithic flakes, burnt limestone, and burnt clay. The table also shows the non-artifactual sediment content of the sample.

\begin{tabular}{|c|c|c|c|c|c|c|c|c|c|}
\hline Locus & Stratum & Fraction size & Shell & Bone & $\begin{array}{l}\text { Charred } \\
\text { organics }\end{array}$ & Lithics & $\begin{array}{l}\text { Burnt } \\
\text { limestone }\end{array}$ & Burnt clay & Sediment \\
\hline \multirow[t]{18}{*}{ Mound C } & \multirow[t]{6}{*}{ B } & $2 \mathrm{~mm}$ & 90 & 5 & 0 & 0 & 0 & 0 & 5 \\
\hline & & $\mathrm{I} \mathrm{mm}$ & 73.5 & 20 & 0.5 & 0 & 0 & 0.5 & 5.5 \\
\hline & & $0.5 \mathrm{~mm}$ & 72 & 15 & 8 & 0 & 0 & 0 & 5 \\
\hline & & $0.25 \mathrm{~mm}$ & 20 & 5 & 9 & 0 & 0 & 0 & 66 \\
\hline & & $0.125 \mathrm{~mm}$ & 15 & 2 & 19 & 0 & 0 & I & 63 \\
\hline & & $0.063 \mathrm{~mm}$ & 8 & 2 & 25 & 0 & 0 & 0 & 65 \\
\hline & \multirow[t]{6}{*}{ C } & $2 \mathrm{~mm}$ & 75 & 20 & 2.5 & 0 & 0 & 0 & 2.5 \\
\hline & & $\mathrm{I} \mathrm{mm}$ & 30 & 0 & 10 & 0 & 0 & 0 & 60 \\
\hline & & $0.5 \mathrm{~mm}$ & 13 & 1 & 6 & 0 & 0 & 0 & 80 \\
\hline & & $0.25 \mathrm{~mm}$ & 10 & I & 4 & 0 & 0 & 0 & 85 \\
\hline & & $0.125 \mathrm{~mm}$ & 2 & 0 & 3 & 0 & 0 & 0 & 95 \\
\hline & & $0.063 \mathrm{~mm}$ & I & 0 & 2 & 0 & 0 & 0 & 97 \\
\hline & \multirow[t]{6}{*}{$D$} & $2 \mathrm{~mm}$ & 0 & 0 & 0 & 0 & 0 & 0 & 100 \\
\hline & & $\mathrm{I} \mathrm{mm}$ & 0 & 0 & 0 & 0 & 0 & 0 & 100 \\
\hline & & $0.5 \mathrm{~mm}$ & 0 & 0 & 0 & 0 & 0 & 0 & 100 \\
\hline & & $0.25 \mathrm{~mm}$ & 0 & 0 & 0 & 0 & 0 & 0 & 100 \\
\hline & & $0.125 \mathrm{~mm}$ & 0 & 0 & 0 & 0 & 0 & 0 & 100 \\
\hline & & $0.063 \mathrm{~mm}$ & 0 & 0 & 0 & 0 & 0 & 0 & 100 \\
\hline \multirow[t]{24}{*}{ Unit 2 (anthropic soil) } & \multirow[t]{6}{*}{$\mathrm{C}_{\text {west }}$} & $2 \mathrm{~mm}$ & 0 & 90 & 0 & 10 & 0 & 0 & 0 \\
\hline & & $\mathrm{Imm}$ & 10 & 60 & 20 & 0 & 1 & 0 & 9 \\
\hline & & $0.5 \mathrm{~mm}$ & 10 & 33 & 7 & 0 & 0 & 0 & 50 \\
\hline & & $0.25 \mathrm{~mm}$ & 20 & 60 & 5 & 0 & 0 & 0 & 15 \\
\hline & & $0.125 \mathrm{~mm}$ & 3 & I & 6 & 0 & 0 & I & 89 \\
\hline & & $0.063 \mathrm{~mm}$ & 0 & I & 5 & 0 & 0 & I & 93 \\
\hline & \multirow[t]{6}{*}{$\mathrm{C}_{\text {mid }}$} & $2 \mathrm{~mm}$ & 60 & 4 & 5 & I & 15 & 15 & 0 \\
\hline & & $\mathrm{Imm}$ & 50 & 35 & 3 & 0 & 10 & 0 & 2 \\
\hline & & $0.5 \mathrm{~mm}$ & 35 & 55 & 1.5 & 0 & 0 & I & 7.5 \\
\hline & & $0.25 \mathrm{~mm}$ & 4 & 4 & 6 & 0 & 0 & i & 85 \\
\hline & & $0.125 \mathrm{~mm}$ & 4 & 3 & 9 & 0 & 0 & 1 & 83 \\
\hline & & $0.063 \mathrm{~mm}$ & 5 & 0.8 & 4 & 0 & 0 & 0.2 & 90 \\
\hline & \multirow[t]{6}{*}{$C_{\text {east }}$} & $2 \mathrm{~mm}$ & 28 & 70 & 0 & 2 & 0 & 0 & 0 \\
\hline & & $\mathrm{I} \mathrm{mm}$ & 40 & 50 & 9 & I & 0 & 0 & 0 \\
\hline & & $0.5 \mathrm{~mm}$ & 30 & 60 & 3 & I & 0 & I & 5 \\
\hline & & $0.25 \mathrm{~mm}$ & 25 & 30 & 10 & 0 & 0 & I & 34 \\
\hline & & $0.125 \mathrm{~mm}$ & 3 & 5 & I & 0 & 0 & I & 90 \\
\hline & & $0.063 \mathrm{~mm}$ & 1 & 2 & 7 & 0 & 0 & 0 & 90 \\
\hline & \multirow[t]{6}{*}{$\mathrm{D}$} & $2 \mathrm{~mm}$ & 85 & 11 & 1 & 1 & 2 & 0 & 0 \\
\hline & & $\mathrm{I} \mathrm{mm}$ & 64 & 21 & 5 & 2 & 6 & 2 & 0 \\
\hline & & $0.5 \mathrm{~mm}$ & 78 & 15 & 3 & 0 & 2 & 1.5 & 0.5 \\
\hline & & $0.25 \mathrm{~mm}$ & 41 & 21 & 10 & 0 & 2 & 10 & 16 \\
\hline & & $0.125 \mathrm{~mm}$ & 22 & 10 & 3 & 0 & 0 & 0 & 65 \\
\hline & & $0.063 \mathrm{~mm}$ & 25 & 4 & 10 & 0 & I & 0 & 60 \\
\hline
\end{tabular}


Table 5. (Continued)

\begin{tabular}{|c|c|c|c|c|c|c|c|c|c|}
\hline Locus & Stratum & Fraction size & Shell & Bone & $\begin{array}{l}\text { Charred } \\
\text { organics }\end{array}$ & Lithics & $\begin{array}{l}\text { Burnt } \\
\text { limestone }\end{array}$ & Burnt clay & Sediment \\
\hline \multirow[t]{24}{*}{ Mound B } & \multirow[t]{6}{*}{ G } & $2 \mathrm{~mm}$ & 98 & I & 0 & 0.5 & 0 & 0 & 0.5 \\
\hline & & $\mathrm{I} \mathrm{mm}$ & 90 & 8 & 0.5 & 0 & I & 0 & 0.5 \\
\hline & & $0.5 \mathrm{~mm}$ & $\mathrm{n} / \mathrm{a}$ & $\mathrm{n} / \mathrm{a}$ & $\mathrm{n} / \mathrm{a}$ & $\mathrm{n} / \mathrm{a}$ & $\mathrm{n} / \mathrm{a}$ & $\mathrm{n} / \mathrm{a}$ & $\mathrm{n} / \mathrm{a}$ \\
\hline & & $0.25 \mathrm{~mm}$ & 39 & 15 & 5 & 0 & 9 & 0 & 32 \\
\hline & & $0.125 \mathrm{~mm}$ & 18 & 6 & 5 & 0 & 0 & 0 & 71 \\
\hline & & $0.063 \mathrm{~mm}$ & 0 & 6 & 10 & 0 & 0 & 0 & 84 \\
\hline & \multirow[t]{6}{*}{$\mathrm{H}$} & $2 \mathrm{~mm}$ & 68 & 30 & 0 & 0 & 2 & 0 & 0 \\
\hline & & $\mathrm{Imm}$ & 45 & 45 & 1.5 & 0 & 0 & 0 & 8.5 \\
\hline & & $0.5 \mathrm{~mm}$ & 39 & 28.5 & 3 & 0 & 0 & 0 & 29.5 \\
\hline & & $0.25 \mathrm{~mm}$ & 12 & 9 & 5 & 0 & 0 & 0 & 74 \\
\hline & & $0.125 \mathrm{~mm}$ & 3 & 5 & 6 & 0 & 0 & 0 & 86 \\
\hline & & $0.063 \mathrm{~mm}$ & 5 & 3 & 10 & 0 & 0 & 0 & 82 \\
\hline & \multirow[t]{6}{*}{ I } & $2 \mathrm{~mm}$ & 60 & 30 & 0 & 0 & 0 & 0 & 10 \\
\hline & & $\mathrm{Imm}$ & 60 & 20 & 5 & 0 & 0 & 0 & 15 \\
\hline & & $0.5 \mathrm{~mm}$ & 20 & 12 & 7 & 0 & 0 & 0 & 61 \\
\hline & & $0.25 \mathrm{~mm}$ & 11 & 13 & 6 & 0 & 0 & 0 & 70 \\
\hline & & $0.125 \mathrm{~mm}$ & 2 & I & 7 & 0 & 0 & 0 & 90 \\
\hline & & $0.063 \mathrm{~mm}$ & 2 & 0 & 8 & 0 & 0 & 0 & 90 \\
\hline & \multirow[t]{6}{*}{ J } & $2 \mathrm{~mm}$ & 95 & 4.5 & 0 & 0 & 0 & 0.5 & 0 \\
\hline & & $\mathrm{Imm}$ & 95 & 3 & 0 & 0 & 0 & I & I \\
\hline & & $0.5 \mathrm{~mm}$ & 92 & 6 & 1 & 0 & 0.5 & 0.5 & 0 \\
\hline & & $0.25 \mathrm{~mm}$ & 85 & 5 & 3 & 0 & 0 & 2 & 5 \\
\hline & & $0.125 \mathrm{~mm}$ & 40 & 1 & 10 & 0 & 0 & 1 & 48 \\
\hline & & $0.063 \mathrm{~mm}$ & 22 & 0 & 21 & 0 & 0 & 2 & 55 \\
\hline
\end{tabular}

samples were placed in the furnace covered with lids, and fired at $650^{\circ} \mathrm{C}$ for $1 \mathrm{~h}$ (Clark, 1996). After the first firing stage, the furnace was switched off and left closed for 20 min. After this, the lids were removed from the crucibles, and the furnace was run for another $45 \mathrm{~min}$ after reaching optimal temperature. The furnace was then switched off, and the door was opened briefly to ensure it contained atmospheric oxygen. Samples were allowed to cool in the oven, weighed, placed in diamagnetic containers, and measured in low and high frequencies. Mass specific magnetic susceptibility, presented in units of $10^{-6} \mathrm{~m}^{3 /}$ $\mathrm{kg}$, was calculated using the following formula: $\chi=\kappa /$ mass $/ 10$. Mass specific frequency dependence is presented as a percentage of $\chi_{\mathrm{LF}}$ and $\chi_{\mathrm{HF}}$ and is calculated as $\left(\chi_{\mathrm{LF}}-\chi_{\mathrm{HF}}\right) / \chi_{\mathrm{LF}}$. Fractional conversion $\left(\chi_{\text {conv }}\right)$ is also presented as a percentage, calculated using the following formula: $\chi_{\mathrm{conv}}=\chi_{\mathrm{LF}} / \chi_{\max }$ (Dearing, 1999; Goldberg and Macphail, 2006).

\section{Results for Angostura}

The surface before occupation is identified as a soil that formed under forested conditions. After the initial forest clearing, which was dated to ca. $4.4 \mathrm{ka}$ on mound B layer 5 (see Table 2), the site presents layers of tightly packed shells (Stratum J, ca. $30-50 \mathrm{~cm}$ on mounds B and D) with little or no other food remains, with dates between 4.1 and $3.6 \mathrm{ka}$. The geoarchaeological analysis of the sample from mound B suggests this layer is the product of anthropic activity. Low OM and fine sediment content suggests it was accumulated rapidly. The lower phosphate levels, sediment composition comprising mostly of three mollusk species (Crassostrea rhyzophorae, Phacoides pectinatus, and Anomalocardia brasiliana), and low microartifact content (Table 4) and diversity (Table 5) suggest that these layers were deliberately created and were not just a random accumulation of food refuse. The bones within the deposit could have been the main source of phosphates.

These shell layers are covered with a 5- to 8 -cm-thick loamy deposit (dates between 4 and $3.8 \mathrm{ka}$ ) with very high microartifact content - particularly tiny bones and shell fragments at $0.125 \mathrm{~mm}$ fraction and coarser (see Table 5) - but with few or no large artifacts. This loamy layer seems to have been created by intentionally covering the shell layers (Stratum J) with locally sourced fine-grained sediments, producing a surface similar in texture to the originally cleared forest floor. The geoarchaeological characteristics suggest that this loamy layer was used as a habitation surface. The shells over the forest floor would have given better drainage capacity than the clay-over-limestone surface.

Analysis of the radiocarbon dates from Angostura suggests that the site was occupied before the $3.5 \mathrm{ka}$ wet period and that it continued being occupied after it (see Figure 4 and Table 2). Radiocarbon dates for the black anthrosol deposits suggest a much later phase of microlandscape use within the site, ca. $2.1 \mathrm{ka}$ for the deeper section of the deposit. Therefore, the area in between the mounds seems to have been clear of anthropic activity at the time the mounds were being actively modified. The deepest sediments at the site (Unit 2), underlying the anthrosols, indicate the area was flooded, at least intermittently, with common changes in water table levels, as suggested by the presence of ferrous nodules and iron staining of the matrix.

The earliest date reported for the growth phase in the speleothem is 3903 corrected ka (see Table 1). The earliest date reported for the shell layers in Angostura is $4.1 \mathrm{ka}$ (GX-28814, 44133860 cal. BP, median 4108 cal. BP, $3740 \pm 100$, calibrated $95.4 \%$, $2 \sigma$ probability). The time discrepancy between the earliest shell layer and the earliest date of the speleothem could be an artifact of the low precision of the radiocarbon date compared with the U/Th date of the speleothem and the palimspest effect of archaeological sites. The median for the other two dates for this layer correspond to 3.6 and $4.0 \mathrm{ka}$ (Table 2). The average of the date falls at about $3.8 \mathrm{ka}$, within the 3.9-3.1 ka wet period. The deposition of shell layers at Angostura could be seen as an immediate response to the beginning of the wet period.

The distribution of the radiocarbon dates from the anthropogenic layers on Mound B suggests that these habitation surfaces were maintained and expanded throughout their use-life. Later, 


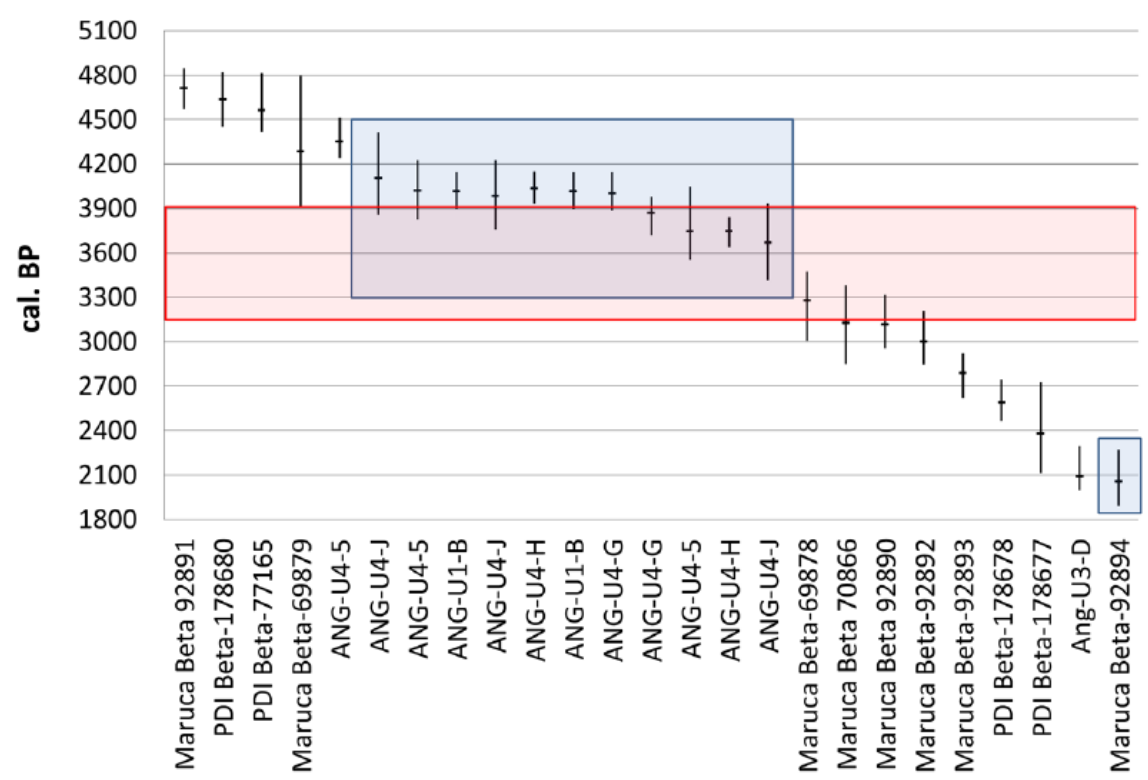

Figure 4. Calibrated radiocarbon dates (median marked) from the sites of Maruca, Paso del Indio (PDI), and Angostura (ANG). The Angostura dates are identified by locus (Mound $B=U 4$, Mound $C=U I$, and Unit 3/Anthropic soil $=U 3$ ), and layer/stratum. The lab number for all the Angostura dates plotted in this table can be found in Table 2. The light gray area (red online) marks the time frame of the $3.5 \mathrm{ka}$ growth period. The darker colored areas (blue online) highlight the dates from Angostura. The table shows that all three sites were inhabited before and after the $3.5 \mathrm{ka}$ growth period. While Angostura continued to be inhabited throughout. Reoccupation at Maruca coincides with the end of the wet period as registered in the Palco speleothem. The stratigraphic correlation of this information is summarized in Table 6.

Table 6. Chronological depiction of the archaeological records of Angostura, Maruca, and Paso del Indio (PDI) in relation to the Palco PA $2 \mathrm{~b}$ speleothem. Dashed lines mark changes with broad beginning or ending date ranges.

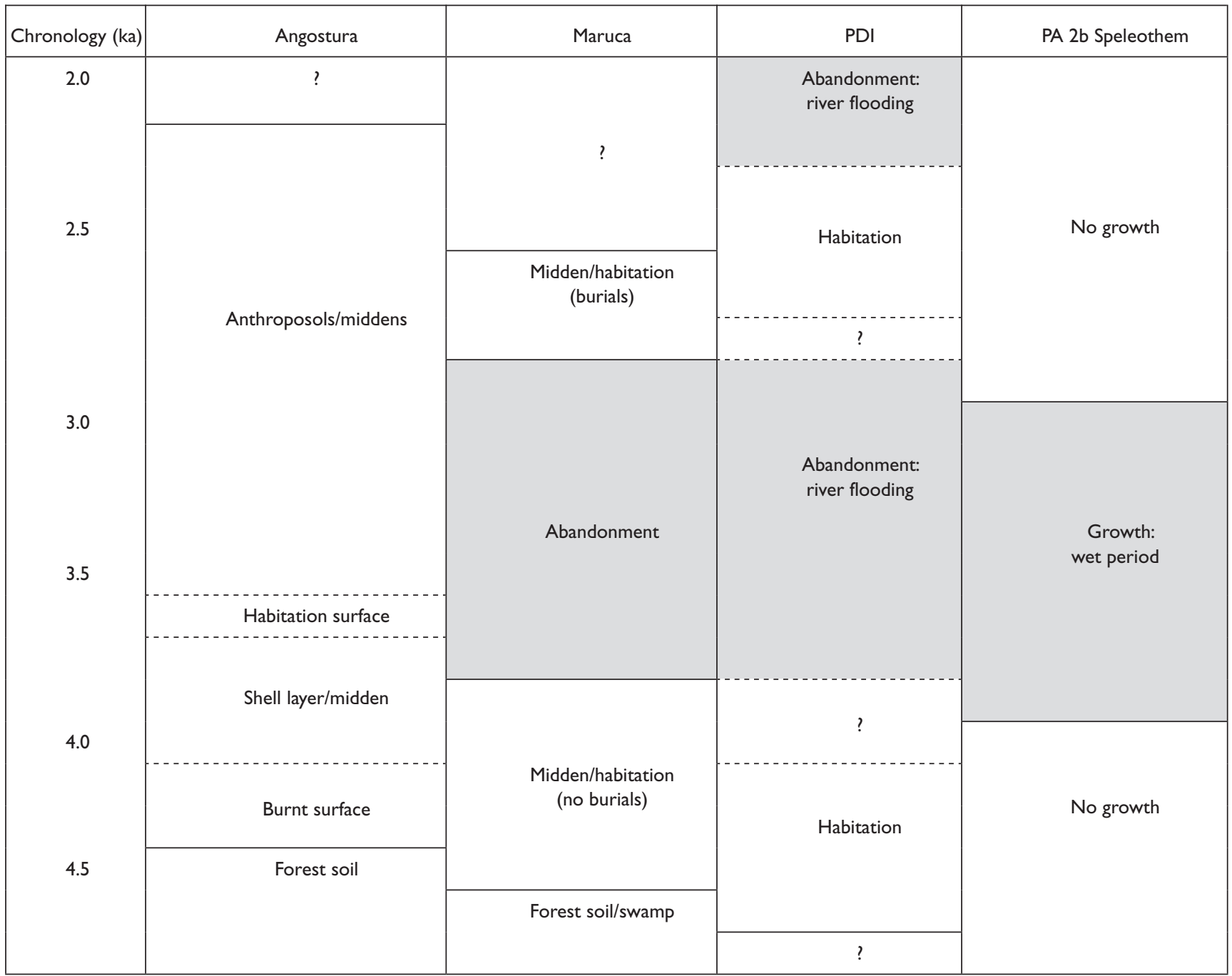


undated archaeological deposits indicate that surface use within the site changed, with the formation of different shell deposits and the beginning of anthropic soils, which were already formed by $2.1 \mathrm{ka}$.

The geoarchaeological analysis suggests that deposition and site formation occurred continuously. Field sieved samples were recovered every $10 \mathrm{~cm}$ and bulk samples were collected for all strata. Given the low energy of the depositional environment where Angostura is located, the coarse fraction of the granulometry analysis (Table 2) can be assumed to be anthropogenic. This was corroborated by the artifact/microartifact ratio (Table 4) observed for each strata per volume. High phosphorous and magnetic susceptibility ratios also correlate to anthropogenic strata (Table 2). Sedimentologically, no interruption of deposition was identified, and all levels with lower coarse content in the granulometry analysis contained high microartifact content in multiple fractions down to $0.25 \mathrm{~mm}$ (Table 5), emphasizing the relevance of in situ human activity over site formation processes. All these characteristics support the interpretation of Angostura as a permanently occupied, sedentary settlement.

\section{Comparison of Angostura, Maruca, and PDI}

The pattern of continued occupation identified in Angostura is not evident at the other two contemporaneous archaeological sites: Maruca and PDI (see Figure 1 and Table 6). Maruca is located directly south of the cave sampled for climate reconstruction, south-southwest of Angostura, on the opposite coast of the island. The area is drier, mostly because of the rainshadow caused by the Central Cordillera. Even though today the site is away from the shoreline, at the time of occupation, the site was located on the coast, within mangrove forests (Rodríguez, 1997, 2004). No geoarchaeological analysis was conducted at Maruca, but the stratigraphic and technological analyses of the site suggest that there were two distinct occupation events (Rodríguez, 2004). The earliest one presents dates from 4.5 to $3.9 \mathrm{ka}(4568-3905 \mathrm{cal}$. BP), and the later from 3.2 to $2.1 \mathrm{ka}(3280-2060 \mathrm{cal}$. BP). These two occupations are separated by a sediment layer identified as an abandonment phase. Human burials are found in association to the later phase of occupation (Rodríguez, 2004).

PDI is located east of Angostura, on the west bank of the Cibuco River on the narrow (ca. $400 \mathrm{~m}$ wide) floodplain within the boundaries of cliffs eroded by the river on the limestone bedrock. The site contains occupation layers starting at the PreArawak period continuing to the present. Distinct occupations are separated by river flood events. The analysis of the rich assemblage recovered has not been completed yet, but brief accounts of the excavation (Rodríguez Ramos, 2010; Walker, 2005) and a report on the geoarchaeological analysis of the site and its surroundings (grain size analysis and OM content, Clark et al., 2003) allow evaluation of the site. PDI presents three distinct Archaic occupation phases: the first one is dated to ca. $4.6 \mathrm{ka}$, the second one between 2.6 and $2.3 \mathrm{ka}(2610$ and $2400 \mathrm{cal}$. $\mathrm{BP}$ ), and the last one ca. $1.8 \mathrm{ka}$ (1860 cal. BP, AD 90; Rodríguez Ramos, 2010: 46). These occupations are separated by inundation events that left a distinct, coarser grained, lighter colored sediment deposit caused by overbank flow and periodic river flooding (Clark et al., 2003).

\section{Discussion: Human adaptation strategies}

We posit that people at Angostura responded rapidly to increased moisture by creating better draining shell deposits over the limestone outcrops and designed habitation spaces raising the living surfaces from the periodically flooding forest floor because of groundwater surfacing. This is an exciting indication of adaptation to climate variability among early Caribbean populations.

Onsite and offsite landforms at and around Angostura suggest that the climatic parameters of the period under study prompted aquifer recharge and intense spring and river activity (RiveraCollazo, 2011a, 2011b). Coring of coastal plain north of Angostura (Rivera-Collazo, 2011b) suggests that $4.1 \mathrm{ka}$ the area was flooded, with sediments evidencing the existence of a palaeolagoon with marine to brackish environmental conditions and active biotic activity on the muddy bottom (Rivera-Collazo, 2011a, see Table 2 for radiocarbon dates). The $3.5 \mathrm{ka}$ wet period intensified the mid-Holocene wet conditions, prompting lowland flooding.

The PDI context supports this observation, as the Cibuco River turned from a stable to a depositional environment at some point after $4.6 \mathrm{ka}$ (Clark et al. 2003). Wetter conditions and higher river discharge with more common overbank flow would have negatively affected the desirability of previously stable locations. Closer to Angostura, the environmental conditions observed in the palaeolagoon changed gradually as salinity in the lagoon decreased, it became shallower, and there was increased mixing of the water column. Dry-land conditions are evident in some areas of the coastal plain by $1.3 \mathrm{ka}$ (Rivera-Collazo, 2011a: 118-123).

Facing these changing environmental conditions, the archaeological record shows two different types of social response or adaptation strategies to the wetter conditions ca. $3.5 \mathrm{ka}$. The inhabitants of Maruca and PDI seem to have relocated. Both sites present habitation hiatus correlating to the $3.5 \mathrm{ka}$ wet period (Figure 4). In the case of Maruca, even though precipitation parameters can be expected to be lower on the south of the island, the elevation gradient of the area is very low - at sea level today - and minute changes in river discharge or spring activity can be expected to have had drastic effects over the coastline and floodplain. It is possible that flooding reduced dry-land area and other coastal zones were easier to access, but sedimentary analysis of the coastal plain would have to be conducted to evaluate this possibility. So far, the sediments within the site identified as the abandonment layer are reported to be the product of flooding (Rodríguez, 1997, 2004). Reoccupation of Maruca occurred just at the end of the precipitation period, around $3.3 \mathrm{ka}$ (Figure 4), possibly because of the drier conditions south of the Central Cordillera and the local microclimate, but additional research is merited. Sadly, the site was destroyed during construction of a megastore and its parking lot.

PDI shows increased river instability and absence of settlement (Clark et al., 2003). Given that only two radiocarbon samples were analyzed from the Archaic context at PDI, it is not possible to pin down precisely when the Cibuco River flooding regime started, except from ascertaining that it occurred at some point between 4.6 and $2.6 \mathrm{ka}$. The correlation between the abandonment of the earliest occupation event at PDI and the increased precipitation period registered in the speleothem is not completely clear because of a 600 a difference between one and the other.

Analysis of lagoon sediments from the coastal plain just north of PDI suggests that during the abandonment of PDI - and during the $3.5 \mathrm{ka}$ wet period - people could have turned to use coastal zones more intensively. According to Burney et al. (1994), the area surrounding the Tortuguero Lagoon (immediately east of Angostura, Figure 1) began to be affected by human activity possibly as early as $5.9 \mathrm{ka}$, as suggested by micro-charcoal presence in cored sediments. However, the study reports the highest micro-charcoal values precisely between 4.0 and $3.5 \mathrm{ka}$, with a distinct peak at $3.2 \mathrm{ka}$ (Burney et al., 1994). The geological and topographic conditions surrounding Tortuguero Lagoon suggest that the area was not prone to flooding even during mid- to early late-Holocene conditions. Even though Angostura is near Tortuguero (Figure 1), it is outside Tortuguero's catchment area for charcoal particles, as it lies downwind from it. The observed 
micro-charcoal must have been produced close to the lagoon or east of it, where the wind could have picked up and transported the particles. It is possible that groups affected by flooding upriver, such as those living at PDI, relocated to the coastal dry land around Tortuguero. Taking into consideration that social ties acquire more relevance under stressful periods (Adger et al., 2013; Curet, 2005; Curet and Oliver, 1998), proximity to the coast and easier access to the maritime networks could have been an attractive option for Archaic groups at that time.

The archaeological record for the Archaic period supports social continuity and strong bonds between islands and continent throughout the period, starting at least ca. $4.8 \mathrm{ka}$ (Rodríguez Ramos, 2008, 2010: 75-87). Even though abandonment of colonization efforts is a possibility, the cultural continuity before and after the $3.5 \mathrm{ka}$ wet period suggests that people could have moved from PDI or Maruca to other areas while onsite conditions were not favorable, and returned later once conditions improved. Additional research in the area surrounding these sites, including a solid radiocarbon dating program, is needed to understand these coastal landscapes during the Archaic period.

Angostura presents a different adaptation strategy. Instead of site abandonment, the settlement shows the development or implementation of already known technology to improve living conditions, as well as the intensification of micro-surface modification as part of landscape formation (sensu Terrell et al., 2003 and the 'domesticated landscape' concept). Angostura was located at the dry land closest to the shoreline of the palaeolagoon. The aeolianite ridges at the coast today would have provided a smaller range of resources and would have been far from access to - and control of - the resource diversity available at the ecotonal area between forest, estuary, and river. Relocating to the aeolianite ridges - or further into the forest - would increase distance to resources from the diverse habitats available from the ecotone, increasing energy investment for resource procurement, making relocation a less profitable option than adaptation.

It is possible that Angostura also played an important role within a maritime network of social interaction and exchange, where settlement abandonment and relocation would have been counterproductive for the group's priorities. The presence of burials - at least one in primary context and additional remains in possible secondary contexts - within the earlier deposits at Angostura suggests that social ancestry was tied to location (Curet, 2005; Curet and Oliver, 1998), a phenomenon seen in Maruca only after resettling occurred. In the case of Maruca, settlement reshuffling in response to higher precipitation regimes could have affected territorial perception in the later phase of occupation, triggering more intense social identification with a particular location.

\section{Conclusion}

General climatic patterns might have different effects on the landscapes comprised within broad regions, therefore influencing the perception of magnitude, scale, and rate of change for the people living on those landscapes. Broad patterns of climatic change and variability for the mid-Holocene in the Caribbean Region suggest that the Greater Antilles were subject to higher precipitation, lower sea levels, and higher seasonality. Even though these patterns help to frame general processes, their wide scale makes it hard to correlate them to the small-scale data of human responses that can be obtained from archaeological sites. In this work, we compare variations in the archaeological record with scale-compatible climate data by considering climatic records close to the location where human activity occurred and not just broad patterns that might not coincide with people's experiences in the past.

The local palaeoclimatic record presented here suggests that precipitation rates fluctuated during the early stages of island colonization in Puerto Rico (near the end of the mid-Holocene). The speleothem record at Palco2 presents an 800-year wet period that spanned from 3.9 to $3.1 \mathrm{ka}$. The archaeological record corresponding to this period suggests that people living in Puerto Rico at this time perceived this change and responded to it in different ways.

Human responses to change are complex and can vary drastically depending on the social priorities at the time when change is perceived. In the case of Angostura, location was a cultural priority and technology was implemented as an adaptation strategy in response to change. In Maruca and PDI, location was considered less of a priority, and therefore, settlement was abandoned or relocated until favorable conditions returned. The archaeological record of PDI and the Tortuguero Lagoon suggests that access to the coast - and possibly to long-distance networks - played an important role in ensuring social continuation and support. Abandonment of Maruca and PDI, as individual sites, could be interpreted as evidence of vulnerability, as the settlement did not continue through the environmental change. However, we argue that vulnerability or resilience of particular groups needs to be contextualized within broader social processes. Flexibility in the perception of location and the identification of relocation as an acceptable adaptation strategy are resilient social responses, as there is evidence of cultural continuation after the end of the environmental instability. In addition, social response to change cannot be seen as monolithic. Even within single cultural periods, response in different locations can be varied, as human behavior addresses the needs of individual groups with different priorities. This multiplicity of responses can indeed enhance resilience as social support can continue through alliances and exchanges that enhance social bonds that can help buffer catastrophes. Resilience and vulnerability, therefore, have to be qualified in terms of scale of observation and goals of adaptation. This conclusion agrees with Adger et al. (2013) who emphasize the importance of the goals of adaptation in the definition of vulnerability and sustainability.

In conclusion, people respond to the environmental and climatic changes they perceive based on their lived or learned experiences. Therefore, broad palaeoclimatic parameters have to be scaled-down to regions and territories when attempting to articulate climate change and cultural response. In addition, different social groups have different priorities, even within the same culture. As a response to climate or environmental change, people will develop adaptation strategies that fit their own needs, allowing for groups to respond differently to the same environmental phenomenon.

\section{Acknowledgements}

Thanks to Juan Estrella and Jose A Santiago-Seaz for milling the speleothem, Yalitza Gonzalez for running the stable isotope samples, and Rolf Martin Vieten for technical support. We are very grateful for the comments of an unknown reviewer who helped us improve the analysis and presentation of this article.

\section{Funding}

This research was funded, in part, by NSF proposal AGS 1003502, an NSF GRFP grant DGE-0632985 and a 2010 Wenner Gren Dissertation Fieldwork Grant (grant \#8156). Any opinions, findings, conclusions, or recommendations expressed in this publication are those of the author and do not necessarily reflect the views of the National Science Foundation.

\section{References}

Adger NW, Quinn T, Lorenzoni I et al. (2013) Changing social contracts in climate change adaptation. Nature Climate Change 3: 330-333.

Ayes C (1988) Evaluación Arqueológica Tipo Fase 2. Angostura, Florida Afuera, Barceloneta, Puerto Rico. Report for the 
Consejo para la Protección del Patrimonio Arqueológico Terrestre de Puerto Rico, Institute of Puerto Rican Culture, San Juan, Puerto Rico.

Beck JW, Richards DA, Edwards RL et al. (2001) Extremely large variations of atmospheric $\mathrm{C}-14$ concentration during the last glacial period. Science 292(5526): 2453-2458.

Bertran P, Bonnissent D, Imbert D et al. (2004) Paléoclimat des Petites Antilles depuis 4000 ans BP: l'enregistrement de la lagune de Grand-Case à Saint-Martin. Comptes Rendus Geoscience 336: 1501-1510.

Braconnot P, Joussaume S, De Noblet N et al. (2000) Mid-Holocene and last glacial maximum African monsoon changes as simulated within the paleoclimate modelling intercomparison project. Global and Planetary Change 26: 51-66.

Braconnot P, Otto-Bliesner B, Harrison S et al. (2007) Results of PMIP2 coupled simulations of the Mid-Holocene and last glacial maximum - Part 2: Feedbacks with emphasis on the location of the ITCZ and mid- and high latitudes heat budget. Climate of the Past 3(2): 279-296.

Bullock P, Fedoroff N, Jongerius A et al. (1985) Handbook for Soil Thin Section Description. Wolverhampton: Waine Research.

Burney DA, Burney LP and MacPhee RDE (1994) Holocene charcoal stratigraphy from Laguna Tortuguero, Puerto Rico, and the timing of human arrival on the Island. Journal of Archaeological Science 21: 273-281.

Burns SJ (2002) A 780-year annually resolved record of Indian Ocean monsoon precipitation from a speleothem from south Oman. Journal of Geophysical Research: Atmospheres 107(D20): ACL9-1-ACL9-9.

Cheng H, Edwards RL, Hoff J et al. (2000) The half-lives of uranium-234 and thorium-230. Chemical Geology 169: 17-33.

Clark A (1996) Seeing Beneath the Soil: Prospecting Methods in Archaeology. 2nd edition. London: BT Batsford Ltd.

Clark JJ, Walker J and Rodríguez Ramos R (2003) Depositional history and evolution of the Paso del Indio Site, Vega Baja, Puerto Rico. Geoarchaeology: An International Journal 18(6): 625-648.

Clement AC, Seager R and Cane MA (2000) Suppression of El Niño during the Mid-Holocene by changes in the Earth's orbit. Paleoceanography 15(6): 731-737.

Cruz FW, Karmann I, Viana O et al. (2005) Stable isotope study of cave percolation waters in subtropical Brazil: Implications for paleoclimate inferences from speleothems. Chemical Geology 220: 245-262.

Curet LA (2005) Caribbean Paleodemography: Population, Culture History, and Sociopolitical Processes in Ancient Puerto Rico. Tuscaloosa, AL: University of Alabama Press.

Curet LA and Oliver JR (1998) Mortuary practices, social development, and ideology in Precolumbian Puerto Rico. Latin American Antiquity 9(3): 217-239.

Curtis JH, Brenner M and David AH (1999) Climate change in the Lake Valencia Basin, Venezuela, $\sim 12600 \mathrm{yr}$ BP to present. The Holocene 9(5): 609-619.

Dansgaard W (1964) Stable isotopes in precipitation. Tellus 16: $436-468$

Dearing J (1999) Environmental Magnetic Susceptibility Using the Bartington MS2 System. 2nd Edition. Oxford: Bartington Instruments. Available at: www.bartington.com (accessed November 2013).

Donnelly JP and Woodruff JD (2007) Intense hurricane activity over the past 5000 years controlled by El Niño and the West African monsoon. Nature 447: 465-468.

Fairchild IJ, Smith CL, Baker A et al. (2006) Modification and preservation of environmental signals in speleothems. EarthScience Reviews 75: 105-153.

Fensterer C, Scholz D, Hoffmann DL et al. (2010) ${ }^{230} \mathrm{Th} / \mathrm{U}$-dating of a late Holocene low uranium speleothem from Cuba. IOP
Conference Series: Earth and Environmental Science 9(1): 012015.

Fensterer C, Scholz D, Hoffmann DL et al. (2012) Cuban stalagmite suggests relationship between Caribbean precipitation and the Atlantic Multidecadal Oscillation during the past $1.3 \mathrm{ka}$. The Holocene 22(12): 1403-1410.

Frank N, Braum M, Hambach U et al. (2000) Warm period growth of travertine during the last interglacial in Southern Germany. Quaternary Research 54: 38-48.

García Goyco O (1998) Proposal for the Analytical Studies and Final Report for the Paso del Indio Archaeological Site, Vega Baja, Puerto Rico. Report for the Puerto Rico State Historic Preservation Office, San Juan, Puerto Rico.

García Goyco O and Maurás Casillas A (1993) Proyecto extensión al plan de mitigación arqueológica del Área de Impacto de la Carretera PR-22, sector Paso del Indio, Río Abajo, Vega Baja, Puerto Rico. Report for the Instituto de Cultura Puertorriqueña, San Juan, Puerto Rico.

Goldberg P and Macphail R (2006) Practical and Theoretical Geoarchaeology. Oxford: Blackwell Publishing.

Greer L and Swart PK (2006) Decadal cyclicity of regional midHolocene precipitation: Evidence from Dominican coral proxies. Paleoceanography 21: 1-17.

Gyllencreutz R, Mahiques MM, Alves DVP et al. (2010) Mid- to late-Holocene paleoceanographic changes on the southeastern Brazilian shelf based on grain size records. The Holocene 20(6): 863-875.

Haug G, Hughen KA, Sigman DM et al. (2001) Southward migration of the intertropical convergence zone through the Holocene. Science 293: 1304-1308.

Hellstrom JC (2006) U-Th dating of speleothems with high initial ${ }^{230} \mathrm{Th}$ using stratigraphical constraint. Quaternary Geochronology 1: 289-295.

Higuera-Gundy A, Brenner M, Hodell DA et al. (1999) A 10,300 ${ }^{14} \mathrm{C}$ yr record of climate and vegetation change from Haiti. Quaternary Research 52: 159-170.

Hodell DA, Curtis JH, Jones GA et al. (1991) Reconstruction of Caribbean climate change over the past 10,500 years. Nature 352: 790-793.

Hoffmann DL, Beck JW, Richards DA et al. (2010) Towards radiocarbon calibration beyond $28 \mathrm{ka}$ using speleothems from the Bahamas. Earth and Planetary Science Letters 289(1-2): $1-10$.

Hoffmann DL, Prytulak J, Richards DA et al. (2007) Procedures for accurate $\mathrm{U}$ and $\mathrm{Th}$ isotope measurements by high precision MC-ICPMS. International Journal of Mass Spectrometry 264: 97-109.

Jochum KP, Wilson SA, Abouchami W et al. (2011) GSD-1G and MPI-DING reference glasses for In Situ and Bulk isotopic determination. Geostandards and Geoanalytical Research 35: 193-226.

Jones IC and Banner JL (2003) Estimating recharge thresholds in tropical karst island aquifers: Barbados, Puerto Rico and Guam. Journal of Hydrology 278(1-4): 131-143.

Kaufmann G (2003) Stalagmite growth and palaeo-climate: The numerical perspective. Earth and Planetary Science Letters 214(1-2): 251-266.

Kennedy LM, Horn SP and Orvis KH (2006) A 4000-yr record of fire and forest history from Valle de Bao, Cordillera Central, Dominican Republic. Palaeogeography, Palaeoclimatology, Palaeoecology 231: 279-290.

Kennett DJ, Breitenbach SFM, Aquino VV et al. (2012) Development and disintegration of Maya political systems in response to climate change. Science 338(6108): 788-791.

Lachniet MS, Bernal JP, Asmerom Y et al. (2012) A $2400 \mathrm{yr}$ Mesoamerican rainfall reconstruction links climate and cultural change. Geology 40: 259-262. 
Malaizé B, Bertran P, Carbonel P et al. (2011) Hurricanes and climate in the Caribbean during the past 3700 years BP. The Holocene 21(6): 911-924.

Mayewski PA, Rohling EE, Curt Stager J et al. (2004) Holocene climate variability. Quaternary Research 62: 243-255.

Miller TE (2004) Cave development and structural control in Cretaceous carbonates, Southern Puerto Rico. Caribbean Journal of Science 40(2): 276-280.

Miller TE (2009) Puerto Rico (caves and karst) In: Palmer AN and Palmer MV (eds) Caves and Karst of the U.S.A. Huntsville, AL: National Speleological Society, pp. 332-337, 339-343.

Milne GA, Long AJ and Bassett SE (2005) Modelling Holocene relative sea-level observations from the Caribbean and South America. Quaternary Science Reviews 24: 1183-1202.

Moy CM, Seltzer GO, Rodbell DT et al. (2002) Variability of El Niño/Southern Oscillation activity at millennial timescales during the Holocene epoch. Nature 420(6912): 162-165.

Nyberg J, Kuijpers A, Malmgren BA et al. (2001) Late Holocene changes in precipitation and hydrography recorded in marine sediments from the northeastern Caribbean Sea. Quaternary Research 56: 87-102.

Pagán Jiménez JR (2007) De antiguos pueblos y culturas botánicas en el Puerto Rico indígena. El archipiélago Borincano y la llegada de los primeros pobladores agroceramistas (BAR International Series 1687). Oxford: British Archaeological Reports.

Pagán Jiménez JR (2011) Early phytocultural processes in the pre-Colonial Antilles: A pan-Caribbean survey for an ongoing starch grain research. In: Hofman CL and Duijvenbode AV (eds) Communities in Contact. Essays in Archaeology, Ethnohistory and Ethnography of the Amerindian Circum-Caribbean. Leiden: Sidestone Press, pp. 87-116.

Pantel AG (1994) Evaluación de Recursos Culturales de Fase II. Yacimiento Precolombino Maruca, Barrio Canas. Municipio de Ponce, Puerto Rico. Submitted to the Consejo para la Protección del Patrimonio Arqueológico Terrestre de Puerto Rico. Report for the Institute of Puerto Rican Culture, San Juan, Puerto Rico.

Peros MC, Reinhardt EG and Davis AM (2007) A 6000-year record of ecological and hydrological changes from Laguna de la Leche, north coastal Cuba. Quaternary Research 67: 69-82.

Proctor CJ, Baker A, Barnes WL et al. (2000) A thousand year speleothem proxy record of North Atlantic climate from Scotland. Climate Dynamics 16(10/11): 815.

Renken RA, Ward WC, Gill IP et al. (2002) Geology and Hydrogeology of the Caribbean Islands Aquifer System of the Commonwealth of Puerto Rico and the U.S. Virgin Islands. U.S. Geological Survey Professional Paper 1419. Reston, VA: U.S. Geological Survey.

Richards DA and Dorale JA (2003) Uranium-series chronology and environmental applications of speleothems. In: Bourdon B, Henderson GM, Lundstrom CC et al. (eds) Uranium-Series Geochemistry. Washington, DC: Mineralogical Society of America, pp. 407-460.

Rivera-Collazo I (2011a) Between land and sea in Puerto Rico: Climates, coastal landscapes and human occupations in the mid-Holocene Caribbean. PhD Thesis, Institute of Archaeology, University College London.

Rivera-Collazo I (2011b) Palaeoecology and human occupations during the mid-Holocene in Puerto Rico: The case of Angostura. In: Hofman CL and Duijvenbode AV (eds) Communities in Contact. Essays in Archaeology, Ethnohistory and Ethnography of the Amerindian Circum-Caribbean. Leiden: Sidestone Press, pp. 407-420.

Rivera-Collazo I (2011c) The ghost of Caliban: Island archaeology, insular archaeologists and the Caribbean. In: Curet AL (ed.) Islands in the Stream: Interisland and Continental Inter- action in the Caribbean. Tuscaloosa, AL: University of Alabama Press, pp. 22-40.

Rodríguez M (1997) Excavations at Maruca, a preceramic site in southern Puerto Rico. In: Rodríguez M (ed.) Proceedings of the Seventeenth Congress of the International Association for Caribbean Archaeology. Nassau, Bahamas, 21-26 July, pp. 166-180.

Rodríguez M (2004) Informe final. Excavaciones en el yacimiento Arcaico de Maruca, Ponce, Puerto Rico. Un proyecto arqueológico auspiciado por el Instituto de Cultura Puertorriqueña. Report for the Consejo para la Protección del Patrimonio Arqueológico Terrestre de Puerto Rico, Institute of Puerto Rican Culture, San Juan, Puerto Rico.

Rodríguez Ramos R (2008) From the guanahatabey to the archaic of Puerto Rico: The non-evident evidence. Ethnohistory 55:393-415.

Rodríguez Ramos R (2010) Rethinking Puerto Rican Precolonial History. Tuscaloosa, AL: University of Alabama Press.

Rosen A and Rivera-Collazo I (2012) Climate change, adaptive cycles and the persistence of foraging economies during the late Pleistocene/Holocene transition in the Levant. Proceedings of the National Academy of Sciences (PNAS) 109(10): 3640-3645.

Scholz D and Hoffmann DL (2011) StalAge - An algorithm designed for construction of speleothem age models. Quaternary Geochronology 6: 369-382.

Scholz D, Tolzmann J, Hoffmann DL et al. (2014) Diagenesis of speleothems and its effect on the accuracy of ${ }^{230} \mathrm{Th} / \mathrm{U}$-ages. Chemical Geology 387: 74-86.

Taylor RG, Scanlon B, Döll P et al. (2013) Ground water and climate change. Nature Climate Change 3: 322-329.

Terrell JE, Hart JP, Barut S et al. (2003) Domesticated landscapes: The subsistence ecology of plant and animal domestication. Journal of Archaeological Method and Theory 10(4): 323-368.

Van Beynen PE, Asmerom Y, Polyak V et al. (2007) Variable intensity of teleconnections during the late Holocene in subtropical North America from an isotopic study of speleothem from Florida. Geophysical Research Letters 34: L18703. DOI: 10.1029/2007GL031046.

Vega J (2000) Evaluación del impacto al Montículo A, sitio Angostura, margen Carr. PR-204, Barceloneta, Puerto Rico. Report for the Consejo para la Protección del Patrimonio Arqueológico Terrestre de Puerto Rico, Institute of Puerto Rican Culture, San Juan, Puerto Rico.

Walker J (2005) The Paso del Indio Site, Vega Baja, Puerto Rico: A progress report. In: Siegel PE (ed.) Ancient Borinquen: Archaeology and Ethnohistory of Native Puerto Rico. Tuscaloosa, AL: University of Alabama Press, pp. 55-87.

Wanner H, Beer J, Bütikofer J et al. (2008) Mid- to Late Holocene climate change: An overview. Quaternary Science Reviews 27: 1791-1828.

White WB (2004) Paleoclimate records from speleothems in limestone caves. In: Sasowsky ID and Mylroie JE (eds) Studies of Cave Sediments. New York: Kluwer Academic, pp. 135-175.

Winter A, Miller T, Kushnir Y et al. (2011) Evidence for 800 years of North Atlantic multi-decadal variability from a Puerto Rican speleothem. Earth and Planetary Science Letters 308, 23-28.

Winter A, Vieten R-M, Miller T et al. (2014) Why was there increased moisture in the eastern Caribbean when Europe was cold? Evidence from Speleothems (EGU General Assembly, Vienna). Geophysical Research Abstracts 16: EGU20148710-1.

Woodruff J, Donnelly JP, Emanuel K et al. (2008a) Assessing sedimentary records of paleohurricane activity using modeled hurricane climatology. Geochemistry, Geophysics, Geosystems 9(9): Q09V10. 
Woodruff J, Donnelly JP, Mohrig D et al. (2008b) Reconstructing relative flooding intensities responsible for hurricane-induced deposits from Laguna Playa Grande, Vieques, Puerto Rico. Geology 36(5): 391-394.

Zak K, Richter DK, Filippi M et al. (2012) Coarsely crystalline cryogenic cave carbonate - A new archive to estimate the Last
Glacial minimum permafrost depth in Central Europe. Climate of the Past 8: 1821-1837.

Zhang HC, Ma YZ, Wünnemann B et al. (2000) A Holocene climatic record from arid northwestern China. Palaeogeography, Palaeoclimatology, Palaeoecology 162(3-4): 389-401. 